\title{
STERILISASI ALAT KEDOKTERAN GIGI DENGAN STERILISATOR (DRY HEAT) DAN TEKNIK BOILING
}

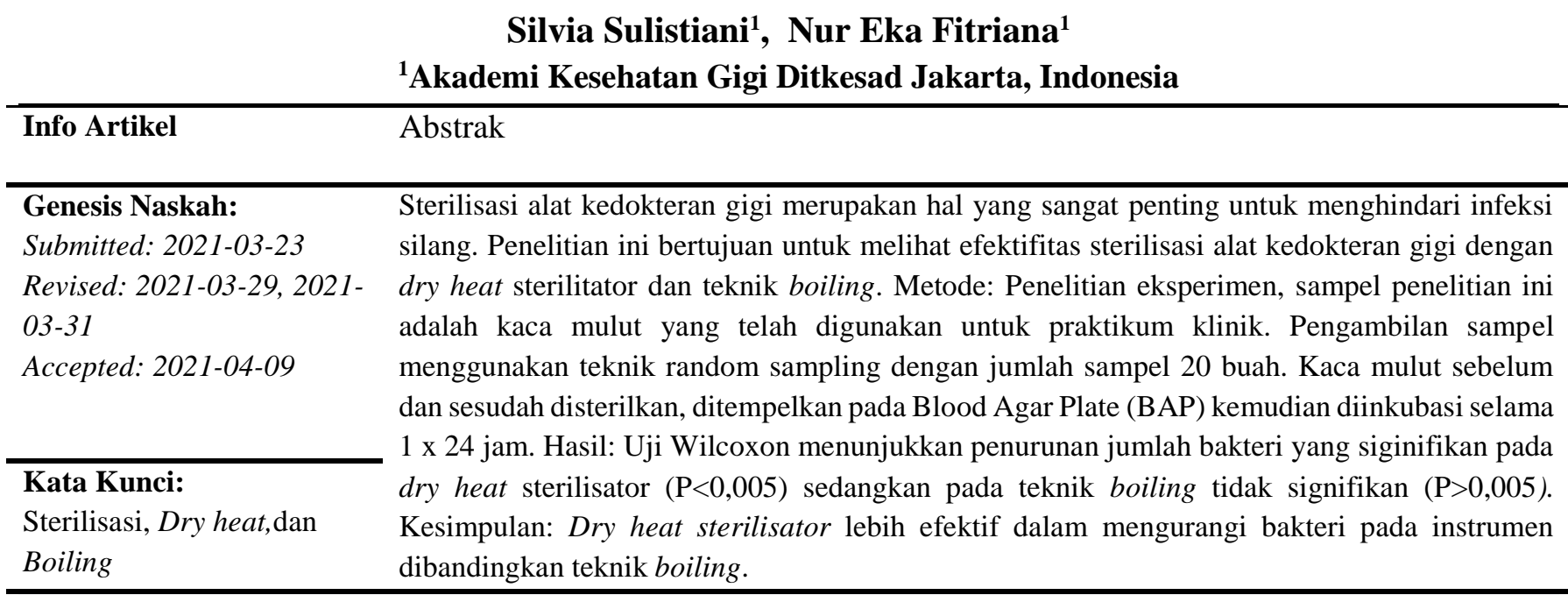

\section{DENTAL INSTRUMENT STERILIZATION WITH STERILIZATOR}

(DRY HEAT) AND BOILING TECHNIQUE

\begin{tabular}{|c|c|}
\hline Keywords: & Abstract \\
\hline $\begin{array}{l}\text { Sterilization, Dry heat and } \\
\text { Boiling }\end{array}$ & $\begin{array}{l}\text { Sterilization of dental instruments is very important to avoid cross infection. This study aims to } \\
\text { determine the effectiveness of the sterilization of dental instruments using dry heat sterilizers } \\
\text { and boiling techniques. Methods: Experiment research, the sample of this study is a mouth } \\
\text { mirror that has been used for clinical practice. Random sampling technique was used with a } 20 \\
\text { pieces of sample. Before and after being sterilized, the mouth mirror was attached to the Blood } \\
\text { Agar Plate (BAP) and incubated for } 1 \mathrm{x} 24 \text { hours. Results: The Wilcoxon test showed that the } \\
\text { decrease in the number of bacteria using dry heat sterilizer was significant (P }<0.005 \text { ), while the } \\
\text { boiling technique was not significant (P> } 0.005 \text { ). Conclusion: Dry heat sterilizer is more } \\
\text { effective in reducing bacteria on the instrument than the boiling technique. }\end{array}$ \\
\hline
\end{tabular}

Korespondensi Penulis:

Widi Nurwanti

Jl. Abdul Rahman Raleh No 18 Jakarta Pusat, Indonesia

Email: widinurwanti@gmail.com

(C) Jurusan Keperawatan Gigi Poltekkes Kemenkes Jakarta I J1. Wijaya Kusuma No. 47-48 Cilandak Jakarta Selatan, Indonesia email: jdht@poltekkesjakarta1.ac.id 


\section{Pendahuluan}

Tenaga kesehatan memiliki risiko terpapar infeksi silang dan penyakit menular. Jenis penyakit menular diantaranya TB Paru, Hepatitis, HIV, ISPA dan lain-lain. Infeksi silang adalah perpindahan penyakit antara pasien dan petugas kesehatan dalam lingkungan kesehatan. Perpindahan infeksi memerlukan beberapa persyaratan yaitu adanya sumber infeksi, perantara dan cara perpindahannya (Mulyanti, Sri \& Putri cit. Virginia, 2020).

Menurut (Mulyanti, Sri \& Putri, 2019), ada strategi pencegahan infeksi yang relatif murah, salah satunya dengan memperhatikan proses dekontaminasi dan pembersihan alat-alat kotor serta diikuti dengan sterilisasi atau desinfeksi tingkat tinggi. Metode sterilisasi termasuk tindakan pemanasan kering atau lembab, beragam gas atau cairan bahan kimia, filtrasi, dan radiasi ionasi. Pemilihan sterilisasi bergantung pada bahan material alat yang akan disterilkan, serta organisme yang terlibat (Mustaqimah, 2014).

Sterilisasi adalah metode yang paling aman dan efisien, tetapi kadang di situasi tertentu alat sterilisasi tidak tersedia. Pemanasan kering atau sterilisasi kering (oven) memerlukan suhu yang sangat tinggi sehingga bahan yang disterilkan hanya tertentu saja karena dapat melelehkan bahan lainnya, suhu yang diperlukan adalah $170^{\circ}$ $\mathrm{C}$ untuk 1 jam atau $160^{\circ} \mathrm{C}$ untuk untuk 2 jam (Kemenkes, 2017). Dalam keadaan tidak tersedianya alat sterilisasi, DTT (Desinfeksi Tingkat Tinggi) merupakan cara lain yang dapat diterima. Salah satu teknik DTT yaitu merebus (boiling). Teknik ini dengan cara merebus di dalam air mendidih $\left(100^{\circ} \mathrm{C}\right)$ selama 15-20 menit dihitung setelah air mendidih (Mulyanti, Sri \& Putri, 2019). DTT dilakukan untuk membunuh berbagai mikroorganisme tetapi dilakukan tidak untuk endospora bakteri (Ilah, 2010).

Penelitian (Meliawaty, 2012) menunjukkan bahwa spora Bacillus antrophaeus hancur setelah sterilisasi dengan oven+infrared (menit ke 30-35), atau jumlah spora akan berkurang bila dipanaskan dengan oven+ozon.

Penelitian lain oleh (Yudianti et al., 2017), menunjukkan bahwa alat yang disterilkan menggunakan dry heat sterilisator bebas dari pertumbuhan bakteri E. Coli sedangkan alat yang

(C) Jurusan Keperawatan Gigi Poltekkes Kemenkes Jakarta I J1. Wijaya Kusuma No. 47-48 Cilandak Jakarta Selatan, Indonesia email: jdht@poltekkesjakarta1.ac.id disterilkan dengan teknik rebus rata-rata ditumbuhi bakteri E. Coli. Penelitian tersebut dapat disimpulkan bahwa sterilisasi panas kering lebih efektif menghambat pertumbuhan bakteri dibanding dengan desinfeksi tingkat tinggi teknik rebus.

Belum adanya penelitian tentang sterilisasi alat kedokteran gigi dengan sterilisator (dry heat) dan teknik boiling, serta mengenai diameter bakteri pada alat kedokteran gigi di Akademi Kesehatan Gigi Ditkesad, membuat peneliti tertarik melakukan penelitian dengan judul "Sterilisasi alat kedokeran gigi dengan sterilisator (dry heat) dan teknik boiling".

\section{Metode}

Desain penelitian ini adalah metode experiment. Instrumen kaca mulut dipilih karena merupakan alat dasar yang umumnya dipakai saat praktikum di Klinik Akademi Kesehatan Gigi Ditkesad. Pengambilan sampel menggunakan teknik random sampling yaitu sebanyak 20 buah kaca mulut. Sampel dibagi menjadi dua, yaitu 10 buah disterilkan menggunakan dry heat sterilisator dan 10 buah lainnya disterilkan dengan teknik boiling.

Langkah-langkah pengambilan data:

1. Blood Agar Plate (BAP) dibagi 4 bagian di laboratorium mikrobiologi Akademi Kesehatan Gigi Ditkesad, kemudian menempelkan bagian belakang kaca mulut satu per satu dengan bidang yang luas ke Blood Agar Plate sambil agak ditekan.

2. Alat yang selesai diambil sampel bakterinya dicuci dengan sabun, disikat dan dibilas di bawah air mengalir, dikeringkan dengan handuk bersih dan dilakukan penempelan kode angka kembali tanpa merubah urutan kode angka sebelumnya.

3. Kemudian dilakukan sterilisasi dengan $d r y$ heat sterilisator selama 1 jam pada suhu $170^{\circ} \mathrm{C}$ dan dengan boiling desinfektor selama 15-20 menit dihitung setelah air mendidih.

4. Setelah selesai, tempelkan bagian belakang kaca mulut steril yang mempunyai permukaan luas dengan agak ditekan ke BAP yang sebelumnya telah dibagi 4 sesuai dengan kodenya. 
5. Blood Agar Plate dengan sampel bakteri dari kaca mulut sebelum dan sesudah disterilkan, dibawa ke Laboratorium Mikrobiologi RSPAD Gatot Soebroto untuk diinkubasi selama $1 \times 24$ jam dengan suhu ruangan.

6. Setelah diinkubasi, sampel bakteri dari kaca mulut pada Blood Agar Plate sebelum dan sesudah disterilkan diukur menggunakan jangka sorong.

Data yang didapat kemudian dianalisis menggunakan aplikasi SPSS dengan cara uji normalitas terlebih dahulu, setelah uji normalitas dilakukan analisis untuk melihat perbedaan diameter bakteri sebelum dan sesudah disterilkan menggunakan dry heat sterilitator dan boiling, apabila data normal menggunakan uji paired $t$ test sedangkan data tidak normal menggunakan uji wilcoxon.

\section{Hasil}

Seluruh sampel mengalami perubahan diameter baik setelah disterilisasi dengan dry heat sterilisator dan teknik boiling.

Tabel 1. Diameter bakteri sebelum dan sesudah disterilisasi dengan $d r y$ heat sterilitator

\begin{tabular}{cccc}
\hline No & $\begin{array}{c}\text { Sebelum } \\
(\mathbf{m m})\end{array}$ & $\begin{array}{c}\text { Sesudah } \\
(\mathbf{m m})\end{array}$ & $\begin{array}{c}\text { Perubahan } \\
(\mathbf{m m})\end{array}$ \\
\hline 1 & 28 & 1 & 27 \\
2 & 25 & 3 & 22 \\
3 & 20 & 1 & 19 \\
4 & 25 & 1 & 24 \\
5 & 25 & 0 & 25 \\
6 & 28 & 2 & 26 \\
7 & 22 & 0 & 22 \\
8 & 28 & 0 & 28 \\
9 & 25 & 1 & 24 \\
10 & 25 & 1 & 24 \\
\hline
\end{tabular}

Pada Tabel 1 terlihat bahwa seluruh sampel mengalami penurunan diameter bakteri, sedangkan pada Tabel 2 menunjukkan bahwa terdapat 1 sampel yang mengalami peningkatan

(C) Jurusan Keperawatan Gigi Poltekkes Kemenkes Jakarta I J1. Wijaya Kusuma No. 47-48 Cilandak Jakarta Selatan, Indonesia email: jdht@poltekkesjakarta1.ac.id diameter bakteri, 9 lainnya mengalami penurunan.

Tabel 2. Diameter bakteri sebelum dan sesudah disterilisasi dengan teknik boiling

\begin{tabular}{cccc}
\hline No & $\begin{array}{c}\text { Sebelum } \\
(\mathbf{m m})\end{array}$ & $\begin{array}{c}\text { Sesudah } \\
(\mathbf{m m})\end{array}$ & $\begin{array}{c}\text { Perubahan } \\
(\mathbf{m m})\end{array}$ \\
\hline 1 & 25 & 15 & 10 \\
2 & 30 & 20 & 10 \\
3 & 23 & 18 & 5 \\
4 & 26 & 20 & 6 \\
5 & 30 & 10 & 20 \\
6 & 25 & 20 & 5 \\
7 & 23 & 20 & 3 \\
8 & 25 & 15 & 10 \\
9 & 15 & 20 & 5 \\
10 & 30 & 25 & 5 \\
\hline
\end{tabular}

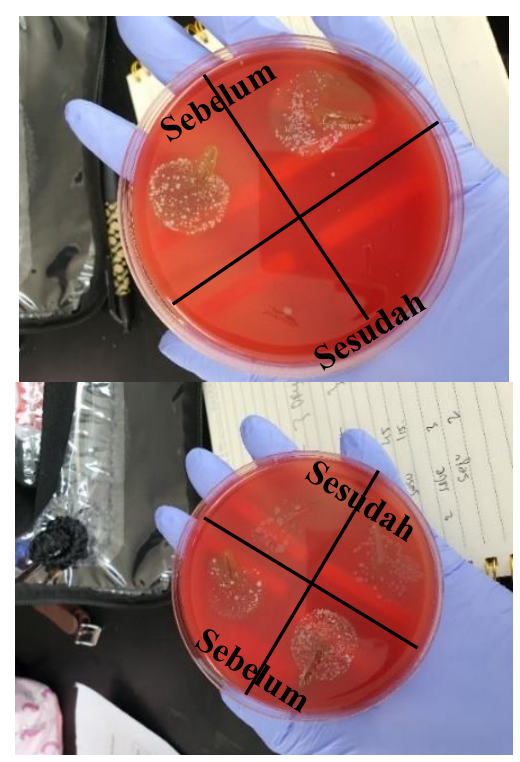

Gambar 1. Contoh hasil penampakan bakteri setelah dilakukan sterilisasi pada instrumen kaca mulut dengan dry heat sterilisator (atas) dan boiling desinfektor (bawah).

Grafik 1 menampilkan rata-rata perubahan bakteri yang disterilkan dengan $d r y$ heat sterilitator adalah $24,1 \mathrm{~mm}$. Pada sampel 
yang disterilkan dengan Teknik boiling, rata-rata perubahan bakteri hanya $7,9 \mathrm{~mm}$.

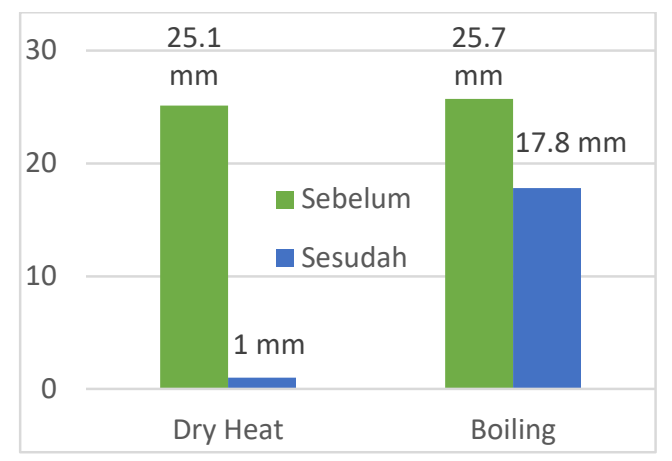

Grafik 1. Rata-rata perubahan diameter bakteri sebelum dan sesudah disterilisasi dengan $d r y$

heat sterilitator dan teknik boiling

Analisis untuk melihat perbedaan diameter bakteri sebelum dan sesudah disterilkan menggunakan dry heat sterilitator dan boiling dilakukan menggunakan uji Wilcoxon (Tabel 3).

Tabel 3. Uji Wilcoxon

\begin{tabular}{cc}
\hline Variabel & $\boldsymbol{p}$-value \\
\hline Dry heat sterilitator & 0,005 \\
Boiling & 0,14 \\
\hline
\end{tabular}

Hasil uji Wilcoxon menunjukkan bahwa teknik dry heat sterilitator menujukkan perubahan diameter bakteri yang signifikan $(\mathrm{p}<0,05)$, sedangkan perubahan bakteri sebelum dan sesudah disterilkan dengan teknik boiling tidak menunjukkan perubahan yang signifikan $(\mathrm{p}>0,05)$.

\section{Pembahasan}

Hasil penelitian tentang sterilisasi alat kedokeran gigi dengan sterilisator (dry heat) dan teknik boiling yang telah dilakukan menunjukkan bahwa terdapat perubahan rata-rata diameter bakteri sebelum dan sesudah disterilisasi dengan dry heat sterilitator dan teknik boiling. Hasil ratarata diameter bakteri sebelum disterilisasi dengan dry heat adalah 25,1 mm. Hasil rata-rata diameter bakteri sesudah disterilisasi dengan dry heat adalah $1 \mathrm{~mm}$, sedangkan hasil rata-rata diameter bakteri sebelum dilakukan teknik boiling adalah $25,7 \mathrm{~mm}$ dan hasil rata-rata diameter bakteri sesudah dilakukan teknik boiling adalah 17,8 $\mathrm{mm}$. Selisih perubahan rata-rata diameter bakteri untuk dry heat adalah $24,1 \mathrm{~mm}$, sedangkan selisih perubahan rata-rata diameter bakteri untuk teknik boiling adalah $7,9 \mathrm{~mm}$.

Penelitian (Raudah, Tien Zubaidah, 2017), menunjukkan bahwa dry heat sterilitator dengan suhu $125^{\circ} \mathrm{C}, 130^{\circ} \mathrm{C}, 135^{\circ} \mathrm{C}$ dapat menurunkan bakteri. Tidak ada perbedaan Hasil sterilsiasi $d r y$ heat yang dilakukan pada penelitian ini menunjukkan penurunan bakteri yang signifikan, namun dapat dilihat pada Tabel 1 bahwa beberapa instrumen masih terdapat sejumlah bakteri. Hasil penelitian lain yang dilakukan oleh (Amir et al., 2013), menunjukkan bahwa masih ditemukan bakteri pada instrumen gigi yang telah disterilkan menggunakan dry heat sterilitator.

Kondisi basah dan lembab setelah disterilkan dengan teknik boiling merupakan lingkungan yang baik bagi bakteri untuk berkembang biak (Yudianti et al., 2017). Hal inilah kemungkinan penyebab hasil perubahan bakteri pada sterilisasi boiling tidak signifikan.

Teknik boiling menggunakan air mendidih pada suhu yang sangat tinggi untuk mencapai desinfeksi. Saat melakukan Teknik boiling, seluruh bagian instrumen harus masuk ke dalam air mendidih dan tidak ada benda lain yang ditambahkan saat air mendidih. Panas yang dihasilkan saat perebusan harus rendah, karena panas tinggi menyebabkan benda memantul, menurunkan permukaan air, dan menghabiskan lebih banyak gas (Acosta-gnass \& Stempliuk, 2009). Teknik yang dilakukan pada penelitian ini sudah sesuai dengan instruksi sterilisasi boiling yang benar.

Suatu metode sterilisasi memiliki keunggulan dan kelemahan dibandingkan metode yang lain. Oleh sebab itu pemilihan metode sterilisasi perlu dipertimbangkan. Ada beberapa faktor yang mempengaruhi penggunaan metode sterilisasi seperti biaya yang dikeluarkan, waktu yang dibutuhkan, orang yang melakukan sterilisasi, suhu dan sebagainya (Mubarak et al., 2019). Dalam hal tidak tersedia alat sterilisasi 
yang memadai, teknik boiling masih dapat dipertimbangkan penggunaannya.

Sterilisasi yang dilakukan pada penelitian ini sudah sesuai dengan standar penggunaan $d r y$ heat sterilisator dan teknik boiling. Hasil yang didapat juga menunjukkan perubahan bakteri sebelum dan sesudah disterilkan, namun pada penelitian ini tidak diketahui bakteri apa saja yang hilang dan masih setelah sterilisasi.

\section{Kesimpulan}

Dry heat sterilisator lebih efektif dalam mengurangi bakteri pada instrumen dibandingkan teknik boiling.

\section{Daftar Pustaka}

Acosta-gnass, S. I., \& Stempliuk, V. de A. (2009). Sterilization manual for health centers. In PAHO Pan American Health Organization.

Amir, A., Dewi, W., \& Wardani, R. (2013). Successful test dry heat oven sterilizer on dental instruments sterilization in $\mathrm{X}$ Hospital. Padjadjaran Journal of Dentistry, 25(3), 163-167.

Ilah, S. (2010). Pencegahan Infeksi dalam Pelayanan Kebidanan. Dee Publish.

Kemenkes. (2017). Pedoman Pencegahan dan Pengendalian Infeksi di Fasilitas Pelayanan Kesehatan.

Meliawaty, F. (2012). Efisiensi Sterilisasi Alat Bedah Mulut melalui Inovasi Oven dengan Ozon dan Infrared Sterilization Efficacy of Oral Surgery Instruments through Innovation of Oven with Ozone and Infrared. $J \mathrm{~km}, 11(2), 147-167$.

Mubarak, M. T., Ozsahin, I., \& Ozsahin, Di. U. (2019). Evaluation of Sterilization Methods for Medical Devices. 2019 Advances in Science and Engineering Technology International Conferences, ASET 2019, 14.

Mulyanti, Sri \& Putri, M. H. (2019). Pengendalian Infeksi Silang di Klinik Gigi. EGC.

Mustaqimah. (2014). Kegawatdaruratan Dental. EGC.

(C) Jurusan Keperawatan Gigi Poltekkes Kemenkes Jakarta I Jl. Wijaya Kusuma No. 47-48 Cilandak Jakarta Selatan, Indonesia email: jdht@poltekkesjakarta1.ac.id
Raudah, Tien Zubaidah, I. S. (2017). Efektifitas Sterilisasi Metode Panas Kering pada Alat Medis Ruang Perawatan Luka Rumah Sakit Dr. Soemarno Sosroatmodjo Kuala Kapuas. Jurnal Kesehatan Lingkungan, 14(1), 425430.

Virginia Rizkaevita, W. N. (2020). Overview of PPE Management Of The Dental Health Worker In Puskesmas Kecamatan Kepulauan Seribu. JDHT Journal of Dental Hygiene and Therapy, 1(18), 12-15.

Yudianti, I., Suprapti, S., \& Hupitoyo, H. (2017). Perbandingan Efektifitas Sterilisasi Panas Kering dan Desinfeksi Tingkat Tinggi Teknik Rebus terhadap Pertumbuhan Escherichia Coli. Jurnal Pendidikan Dan Pelayanan Kebidanan Indonesia, 2(1), 53. 